\title{
YABUUCHI KIYOSHI: HIS LIFE, WORKS AND SIGNIFICANT CONTRIBUTIONS TO THE CHINESE HISTORY OF SCIENCE AND TECHNOLOGY
}

\author{
Isa MaZiliang
}

\section{Introduction}

When I read materials related to Islamic science of astronomy and calendars in China during my doctoral research at the Department of Science and Technological Studies, Faculty of Science, University of Malaya, I frequently encountered a strange Chinese name, Sou Nei Qing (薮内清). The name was cited by many Chinese scholars in their works, especially in Chinese language relating to Islamic science of astronomy in China. However, I initially did not take any special notice as I simply thought that he was just an ordinary Chinese scholar. However, as I began to read more, I kept coming across his name in numerous works. His name was frequently cited whenever Chinese scholars presented an argument on the Islamic science of astronomy in China; his views were always considered authentic and conclusive. Hence, I became interested in knowing more about his background and what made him revered. Since I could not obtain detailed information from existing Chinese textbooks relating to astronomy in China, I referred my Chinese dictionary to search for the meaning of the name, Sou Nei Qing (薮内清). I found “Sou (薮)" in the Chinese language literally meant a big pool or wetland (薮, 大泽也。—《说文: the original Chinese characters indicates “Sou (薮)" as a huge wetland and it could have meant a pool or a lake. "Nei (内)" is a simple word that refers to inside and "Qing (清)" means "clear or clean," so "Sou Nei Qing" literally means "a clear lake or clean wetland full of water." I was puzzled and wondered how this could be a Chinese name. Suddenly, I realized that this was not a Chinese name but it was a Japanese name! the scholar's name was Yabuuchi Kiyoshi (薮内清). Most Chinese scholars did not mention he was a Japanese scholar nor were his publications listed. Some Chinese scholars were obviously biased and they did not want Japanese names to appear in their works. These Chinese scholars did not want to acknowledge that a Japanese scholar had made great contributions to Chinese history of science and technology, including the Islamic science of astronomy, especially the Islamic calendar in China or Hui Hui Li Fa 《回回历法. Professor Yabuuchi was the first scholar to systematically study Tian Gong Kai Wu (《天工开物: Nature's Engineering and Works) which was the first Chinese material on science and technology in China which was later translated into the Japanese language. Professor Yabuuchi was the first foreigner who studied Ben Cao Gang Mu (《本草纲目》: Compendium of Material Medica) outside China and translated some parts of the book into the Japanese language. Professor Yabuuchi was also the first person in the world, who successfully explained how the Islamic calendar, Qi Zheng Tui Bu, was transmitted to China in the early period of the Ming works through the spherical model and trigonometry theory. No Chinese scholar 
could do so before Professor Yabuuchi did. Yabuuchi Kiyoshi is the most suitable person that I should study because he wrote a paper entitled "An Explanation of the Islamic Calendar: 《回回历解》," which is my research topic.

\section{Yabuuchi's Life}

\section{Professor Emeritus Yabuuchi Kiyoshi}

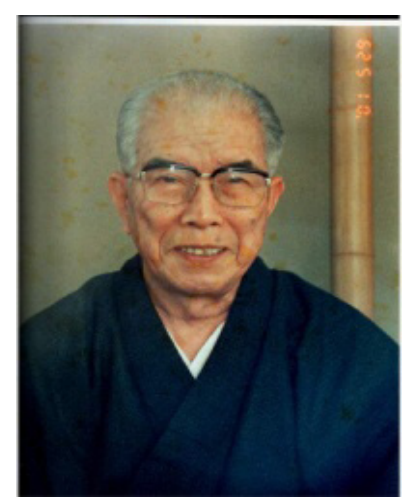

Source: Institute of History of Natural Science, China Academy of Science

Yabuuchi Kiyoshi was a Japanese scholar in the history of science and technology and astronomy. He was born in Kobe on 12 February 1906 and passed away on 2 June 2000 in Kyoto. Having lived for 94 years, I was impressed with his long life and that encouraged me to write a story about his contribution to the Chinese history of science and technology, especially Chinese astronomy. In 1926, Yabuuchi Kiyoshi enrolled at Kyoto University to study at the Department of Astrophysics where he learned the history of science under a distinguished historian of Chinese astronomy, Shinzo Shinjo (新城新藏: 1873-1938). Yabuuchi was also acquainted with a famous historian of Chinese mathematics, Yoshio Mikami (三上義夫: Mikami Yoshio: 16 February 1875-31 December 1950). In 1929, he graduated from the Department of Astrophysics, Kyoto University. After graduation, Yabuuchi was employed by his alma mater as an assistant, where he worked alongside Noda Churyo (能田忠亮: 1901-1989) who was a senior colleague to Yabuuchi Kiyoshi. Yabuuchi also learned Chinese history of science from him. When Shinzo Shinjo was in charge of the Department of Astrophysics, Yabuuchi studied ancient Chinese science of astronomy from him. In 1929, the Japanese government set up the Academy of Oriental Cultural Studies to focus on Chinese cultural studies. Subsequently, a research institute was set up in Kyoto and Tokyo University respectively to deal with this subject. In 1930, Kyoto Research Institute of Academy of Oriental Cultural Studies built a new building in the area of White Rivers, northern zone of Kyoto (Sakyō ku kitashirakawa: 左京区北白川), and this institute was a part of Kyoto University. A room was dedicated to Astronomy and Calendar Studies where its first director was Shinzo Shinjo's student Churyo Noda worked with him.

At that time, Japanese scholars in Kyoto and Tokyo debated the origin of Chinese science of astronomy. On one hand, Tokyo scholars such as Iijima Tadao (饭岛忠夫) felt that the Chinese science of astronomy was influenced by the Greek science of astronomy. On the other hand, Kyoto scholars such as Shinzo Shinjo insisted that the Chinese science of astronomy developed without external influence. 
In this debate, Yabuuchi Kiyoshi held a similar view as Kyoto scholars who asserted that Chinese science of astronomy developed on its own without external influence. Within this context, Yabuuchi began to pay more attention to the subject of Chinese science of astronomy. He decided to take part in the research team led by his guru Shinzo Shinjo along with his senior colleague, Noda Churyo. In order to become a qualified Chinese expert on the subject of Chinese science of astronomy, Yabuuchi started to learn Chinese language seriously. His interest in the language enabled him to understand even classical Chinese textbooks. He also mastered the necessary research skills from his guru and colleagues until he acquired enough knowledge of Chinese history and history of the Chinese science of astronomy. In 1935, he left the Department of Astrophysics, Kyoto University for Astronomy and Calendar Studies which was attached to Kyoto Research Institute of Academy of Oriental Cultural Studie to work under the supervision of Shinzo Shinjo.

In 1936, Yabuuchi published his maiden work entitled "Stars in the period of Song: 《宋代 の星宿》," 《东方学报, in the Journal of Oriental Studies, Kyoto (vol. 7, 1936). A year later, Yabuuchi published his second article entitled "Star Longitudes in the Kai Yuan Zhan Jing of Tang Dynasty: 《唐開元占經中の星經》, 《东方学报, in the Journal of Oriental Studies (vol. 8, 1937). In 1938, Kyoto Research Institute of Academy of Oriental Cultural Studies was renamed Oriental Cultural Research Institute, which was the predecessor to the Institute of Humanity (Jinbun) Studies of the current Kyoto University. In the same year, Shinzo Shinjo resigned and the Room for Astronomy and Calendar Studies began to be headed by Noda Churyo (能田忠亮). Here, Yabuuchi held a research fellowship. In his research, Yabuuchi found that the main feature of the Chinese science of astronomy was to serve the state political needs. The construction and implementation of calendars was a symbol of the state to ackowledge the establishment of a new political power. The core research focused on calculation and construction of calendars, usually carried out by a group of scholarly Confucian officials and not by professional astronomers.

Yabuuchi also noticed that despite changes in the extent to which Chinese dynasties evolved, from one dynasty to another, research culture and structure of organization within the state observatories never changed. Yabuuchi suggested that this was a typical Chinese phenomenon and advised that researches on Chinese history of science should focus on calendars that indicate different periods of Chinese dynasties. In other words, calendars in various historical periods should be the core of research in the area of Chinese history of science and technology.

Yabuuchi is known to have done innovative research in this area between 1940 and 1944. He published several important articles in this period such as "A Study of Calendars in the Two Han Dynasties: 《兩漢暦法考》, “《东方学报, in the Journal of Oriental Studies (vol.11, No.4, 1940). In 1941, he published "China's Calendrical History from Yin Zhou to Sui Dynasty: 《殷周ょり隋に至る支那暦法史》,"《东方 学报, in the Journal of Oriental Studies (vol. 12, no.4, 1941). A year later, he published “The Introduction of Indian Calendar in the Tang Dynasty: 《唐代における天筑暦法 の輸入》," 『京都漢学大会紀要』 in March 1942. In 1943, he published two articles; “Calendrical History in the period of Tang and Sung: 《唐宋暦法史》” 『東方学報』 京都 in the Journal of Oriental Studies (No. 13, September 1943) and "Measurement Technique on Sun Track and Moon Phases in the Calendars of Tang Dynasty: 《唐代暦 法に於ける歩日踑月離術》," 『東方学報』京都, in the Journal of Oriental Studies (No. 13, 1943). In 1944, he published one article "Calendrical History in the period of Yuan and Ming- 《元明暦法史》," 『東方学報』京都 in the Journal of Oriental Studies (No. 14, Feb. 1944). 


\section{Yabuuchi's Achievements and Works}

Yabuuchi was conferred the Degree of Doctor of Philosophy of Science in 1945 after the publication of a book entitled "Research on the History of Calendrical Science in the Sui and Tang Dynasties: 《隋唐曆法史の研究》, Tōkyō: Sanseidō, 三省 堂, in 1944. In 1946, he published an article "Western Astronomy Eastward: Calendrical Science in the Qing Dynasty: 《西洋天文學の東漸一清代の暦法》," 『東方学報』京都, in the Journal of Oriental Studies (No. 15, January 1946). In 1947, he published a challenging article, “The Characteristics of Chinese Science: 《中国科学の性格》”，国民の歴史』 Kokumin no rekisi, (Vol. 1, No. 10, October 1947). These publications enabled him to become a research fellow at Kyoto University in 1948. By 1949, he became a professor at the Institute of Humanity (Jinbun) Studies, at Kyoto University.

In 1950, Yabuuchi published his first article relating to Islamic science of astronomy in China entitled "Islamic Astronomy in China: 《中国に於けるイスラム天文学》,"

《东方学报》 in the Journal of Oriental Studies (Vol. 19, December 1950). In 1951, he published an article entitled “Ancient Chinese Time-Keepers: 《中国の時計》，《科学史 研究》 in the Journal of History of Science (Vol. 19, 1951). In 1953, he published "A Study of Tian Gong Kai Wu: 《天工開物の研究》," Tōkyō: Kōseisha (恒星社) in September 1953. In 1954, he published "European Astronomy Introduced into Modern China: 《 近世中国に伝えられた西洋天文学》, " 科学史研究』in the Journal of History of Science, (No. 32, 1954). In 1956, he published "On the Theories of the Planetary Movement in Chinese Astronomy: 《中国天文学における五星運動論》,"『東方学報』京都 in the Journal of Oriental Studies (No. 26, March, 1956). Two years later, he published "Scientific Thoughts in China: 《中国科学思想》”，『東洋的人間像』(People in the Orient) which was edited by Kamei Katsuichirō (亀井勝一郎) in Tōkyō. In 1959, he published “The Observation Technology in the Han Dynasty and Shishi Xingjing: 《漢代における観測 技術と石氏星経の成立》," 『東方学報』京都 in the Journal of Oriental Studies (No. 30, December 1959). In 1961, he published at least two articles in the Journal of History of Science related to the Chinese history of science, and these articles were "Bureaucracy and its Relations to the Chinese Science in the Middle Age: 《官僚政治と中国中世の科 学》,"『科学史研究』(No. 59) and “Brightness of Inner Planets in Chinese Astronomical Tables: 《中国暦における内惑星の光度》,”『科学史研究』(No. 60). In 1962, he presented a paper entitled "Islamic Astronomy in China" at an international conference held in Paris under the name of Actes du Congres International d'Histoire des Sciences and later his paper was published in 1964. With the publication, Yabuuchi began to be known among French scholars. In another paper, he also discussed Islamic astronomic instruments invented by Zha Ma Lu Ding in the early period of Yuan Dynasty, "The Astronomical Observatory and Observation Instruments in Islam: 《イスラムの天文 台と観測器械》," 『文明の十字路』 in a book entitled The Crossroad of Civilization, edited by the Kyōto University Study Group (京都大学学術調査隊. Tōkyō: Heibonsha: 平凡社, 1962). In 1963, he published several works - "Studies in the History of Science and Technology in Medieval China: 《中国中世科学技術史の研究》 (Tōkyō: Kadokawa Shoten 角川書店, 1963); “Astronomical Tables in China-From the Wutai to the Ch'ing Dynasties," in the History of Science, (No.2, 1963) and "Sciences in China from the fourth to the end of the twelfth century," in History of Mankind edited by Guy S. Métraux and Franzois Crouzet (New York: Mentor Books, 1963). In 1964, he published two very important articles related to the Islamic science of astronomy and calendar - "An Explanation of Islamic Calendar: 《回々暦解》," 『東方学報』in the Journal of Oriental Studies (No. 36, Oct. 1964) and "The Astrological Book of Kūšyār, Persian Astronomer 
at about 1,000 A.D.: 《Kūšyār の占星書》, 『中东、西、南亚アジア研究』, in Middle Eastern Studies of Bulletin of the Society for Western and Southern Asiatic Studies (No. 13, December1964). There were no publications related to Chinese history of science in 1965 though he published many articles in other fields. In 1966, he published "The Development of Science and Technology in the Period of Sung and Yuan: 《 宋元 時代における科学技術の展開》，" 『東方学報』京都 in the Journal of Oriental Studies (No. 37, March 1966) and “Characteristics of Chinese Science: 《中国科学の特質》," 『東洋学術研究』 in the Journal of Oriental Studies (Vol. 5, No. 8, November, 1966). His publications, enabled him to be appointed as the director of the Institute of Humanity (Jinbun: Human Science) Studies, Kyoto University in 1967. In 1969, Yabuuchi retired with Kyoto University honoring him with the title of Professor Emeritus and later he was appointed as a professor at Ryukoku University. In 1972, American Association of History of Science awarded Yabuuchi Kiyoshi the Sarton Medal, which was the highest honor for researchers in the history of science. In 1983, he was elected as a committee member of the Japan Academy. In general, Yabuuchi produced several publications throughout his career. The following is a summary of his selected masterpieces related to Chinese history of science and technology.

\begin{tabular}{|c|c|}
\hline $\mathrm{OO}$ & buuchi's Masterpieces of Works relating to Chin \\
\hline 1 & 支那 の 天 文 学》, 恒星社厚生閣, 1943年。Chinese Astronon \\
\hline 12 & $\begin{array}{l}\text { 《隋唐曆法史の研究》, 三省堂, 1944年。Research on the History of Calendrical Science in the Sui and } \\
\text { ang Dynasty, Sanseido, } 1944 \text {. }\end{array}$ \\
\hline 3 & $\begin{array}{l}\text { 《支那数学史概说》, 山口書店, 1944年。Introduction to the History of Mathematics in China, Yamaguchi } \\
\text { hoten, 1944. }\end{array}$ \\
\hline 4 & $\begin{array}{l}\text { 《汉書律曆志の研究》, 与能田忠亮合作, 全国書屋, 1947年。Res } \\
\text { the Book of Han Dynasty, co-authored with Noda Churyo, Zenku }\end{array}$ \\
\hline 5 & 《中国の天文学》, 恒星社厚生閣, 1949年。Chinese Astronomy, \\
\hline 6 & 《天工開物の研究》, 恒星社, 1953年。Studied on Tia \\
\hline 7 & $\begin{array}{l}\text { 《中国古代科学技術史の研究》, 京大人文研, 1959。A } \\
\text { Ancient China, Institute of Humanity (Jinbun) Studies, K }\end{array}$ \\
\hline 8 & $\begin{array}{l}\text { 《中国中世科学技術史の研究》, 角川書店, 1963年。A Study of } \\
\text { the Medieval China, Kadokawa Shoten 1963. }\end{array}$ \\
\hline 9 & 《中国古代の科学》, 角川新書, 1964年。Science in A \\
\hline 10 & $\begin{array}{l}\text { 《回回暦解》, 日本《东方学报》, 京都36（创立35周1 } \\
\text { Islamic Calendar, Journal of Oriental Studies, Vol.36 }\left(35^{\text {th }}\right.\end{array}$ \\
\hline 11 & $\begin{array}{l}\text { 《宋元時代の科学技術史》， 京大人文研，1967年。Hist } \\
\text { Song and Yuan, Institute of Humanity (Jinbun) Studies, K }\end{array}$ \\
\hline 12 & $\begin{array}{l}\text { 《中国の天文暦法》, 平凡社, 1969年。Science of Astr } \\
\text { and New Edition in } 1990 .\end{array}$ \\
\hline 13 & 《中国の科学文明》, 岩波新書, 1970年。Science anc \\
\hline 14 & $\begin{array}{l}\text { 《明清时代の科学技術史》，京大人文研，1970年。H } \\
\text { Ming and Qing, Institute of Humanity (Jinbun) Studies }\end{array}$ \\
\hline 15 & 《中国の科学と日本》, 朝日新聞社, 1972年。Chines \\
\hline 16 & 《中国文明の形成》, 岩波書店, 1974年。The Formatic \\
\hline 17 & 《中国の数学》, 岩波新書, 1974年。 Mathematics in China, Iw \\
\hline 18 & 《中国の科学と日本》, 朝日新聞社, 1978年。Chinese \\
\hline 19 & $\begin{array}{l}\text { 《科学史からみた中国文明》, 日本放送出版協会〈NHKブックス〉1982年。Chinese Civilization in the } \\
\text { Context of History of Science, Japan Broadcasting Publishing Association, } 1982 .\end{array}$ \\
\hline 20 & 㻟唐暦法史の研究》，増訂版，臨川書店，1989年。1 \\
\hline 21 & $\begin{array}{l}\text { 《中国の天文暦法》，（増補改訂），平凡社，1990年。Astronomy and Calen } \\
\text { (revised and enlarged edition). Tōkyō: Heibonsha 1990. }\end{array}$ \\
\hline
\end{tabular}

Source: Journal of History of Natural Science, Institute of History of Natural Science, China Academy of Science, China; East Asian Science, Technology, and Medicine (EASTM), vol. 18 (2001), pp134-167. This table does not list all publications including books and articles authored by Yabuuchi and irrelevant to Chinese history of science. This list also does not include all co-authored (second author), public speeches and translations of Yabuuchi Kiyoshi. 


\section{Yabuuchi's Significant Contributions}

Japanese scholarly research on Chinese history of science began with studies of history of science of astronomy. In the early years, research in this field was led by Shinzo Shinjo who was the founder of the Room for Chinese Science of Astronomy and Calendar Studies, which was the primogenitor of Institute for History of Science Research, which was attached to Kyoto University. In the early period, research focused on science of astronomy in the pre-Qin era (before 221 B.C). These studies were just part of supplementary courses for Chinese studies, which meant the focus was on year verification for classical texts for the purpose of history and scared compilations. Though some progress was seen, Yabuuchi was dissatisfied; to him the history of science of astronomy was a separate subject from the science of history, and it should not be a subset of history. Further, he was of the opinion that the basic characteristics and features of China and its people determined the extent to which the Chinese science of astronomy developed and this needed to be studied. With this aim, Yabuuchi specialized in the Chinese history of science of astronomy and made the subject independent of the main Chinese syllabus. Yabuuchi's greatest contribution to the history of science was to systematically study Chinese science of astronomy history. His works included the “Chinese Astronomy (1943): 《支那の天文学》," 恒星社, 1943 and “Chinese Astronomy and Calendars: 《中国の天文曆法》," 平凡社, 1969.

While trying to understand the algorithm in the calculation of the Chinese calendar and astronomical mathematics, Yabuuchi made detailed notes on Chinese ancient mathematics. In 1944, he published a book entitled "Studies on Calendrical History of Sui and Tang Dynasty: 《隋唐曆法史の研究》,”三省堂, 1944. He also wrote a book entitled “Introduction to the History of Chinese Mathematics: 《支那数学史概說》", 山口書店, 1944. This book became one of the most important work contributed by Yabuuchi, apart from research conducted by Dr. Yoshio Mikami (三上義夫: 1875-1950). In 1974, Yabuuchi published a book entitled “China's Mathematics: 《中国の数学》," 岩波書店, 1974. In these two great works, he not only summarized great achievements of Chinese ancient mathematics, he also pinpointed developmental features of the Chinese science of mathematics when compared to the West. In this context, Yabuuchi contribution to the study of Chinese astronomical and calendrical mathematics was unmatched elsewhere.

After World War Two, the Kyoto Institute of Oriental Cultural Studies, the Institute of German Cultural Studies and the Institute of Humanities Studies were merged to become the Institute of Humanity (Jinbun: Human Science) Studies, attached to the Kyoto National University. After the retirement of Noda Churyo (能田忠亮), Yabuuchi held the directorship of the Room for the Chinese Science of Astronomy and Calendar Studies and with additional responsibilities of being a professorship at Kyoto University. Yabuuchi changed the name of the Room for Chinese Science of Astronomy and Calendar Studies to Room for Chinese History of Science Studies. Clearly, he wanted to expand the field of study from just the science of astronomy and calendar to the Chinese history of scientific studies. This move represented a futuristic view as well as turned out to be a strategic decision. No such research institute existed globally. Therefore not surprisingly, Yabuuchi is regarded as the founder of Chinese history of scientific studies in Japan, and this became his second greatest contribution to the Chinese history of science. 
Professor Yabuuchi led a research team after the Room for History of Science and Technology Studies was first formed. He selected “Tian Gong Kai Wu: 《天工开物》," a science and technology encyclopedia authored by Song Yingxing (宋应星) in the later Ming Dynasty for his research reference. It served as the starting point to study the Chinese history of science and technology systematically. Yabuuchi and his members of the study group mindfully studied this great book which culminated in eleven critical essays. The essays were published in a book, edited by Yabuuchi Kiyoshi (1953) under the title of “Studies on Tian Gong Kai Wu: 《天工開物の研究》," 恒星社, 1953.

Group brainstorming was the model adopted by this study team and applying this method, they focused on a number of key issues; issues were resolved by using group wisdom and expertise. Through this method, collective wisdom of the group reached its maximum level, leading to excellent results. This study model is maintained till today in the institute. The book edited by Yabuuchi consisted of word corrections and adjustments to the original manuscript, annotations and topic-by-topic discussions. The book is considered the best version of the original manuscript, published outside China. In 1969, he re-edited and simplified it and a new version of "Tian Gong Kai Wu: 《天工开物》" was published. This new version was warmly received by readers and was republished many times in later years. As a result of the publication of this book, Yabuuchi became globally famous. The original version of Tian Gong Kai Wu was translated into Chinese, English, German and Korean. Most translations were based on the version produced by Yabuuchi Kiyoshi. This was one of his great contributions to improving the original version of Tian Gong Kai Wu authored by Song Yingxing ( 宋应星) in 1637, Yabuuchi's the third greatest contribution to the Chinese history of science studies.

In 1957, in order to promote studies on Chinese history of science and technology, Yabuuchi organized more study groups consisting of experts from different fields and backgrounds to study among others, Qi Min Yao Shu (Technique to Help People: 《齐 民要术》, Shang Han Lu (Theory of Typhoid Fever: 《伤寒论》), and Meng Xi Bi Tan (Pen Notes on the side of Dream River: 《梦溪笔谈》). There were also many other famous classical Chinese works related to the history of science and technology which were published in Japanese subsequently. Yabuuchi personally made annotations and illustrations for each book. Yabuuchi was also the chief editor to the Ben Cao Gang Mu (The Compendium of Materia Medica), the newly translated, annotated and edited version in the Japanese language: 《新注校定日译本草纲目》. It is reported to be the best translation of Ben Cao Gang Mu in a foreign language outside of China. Furthermore, Yabuuchi also promoted and introduced excellent works relating to Chinese history of science and technology. The publication was international as well for Japanese readers. In 1940, he co-operated with Professor Shimamoto Kazuo (岛本一男) and translated the History of Chinese Mathematics: 《支那数学史》 originally authored by Li Yan (李俨: 1892-1963, 生活社, 1940年) into Japanese. In 1974, Yabuuchi was in charge of translating the “Science and Civilisation in China: 《中国科学技术史》" originally authored by Joseph Needham (李约瑟: 1900-1995) into the Japanese language. In 1977, Yabuuchi cooperated with Ishibashi Masako (石橋正子) and translated “The Invention of Printing in China and Its Spread Westward: 《中国印刷术的发明及其西传》" originally authored by Luther Carrington Goodrich (1894-1986). The second version was edited by Thomas Francis Carter (1882-1925) and translated into the Japanese language; Professor Yabuuchi also did some annotations in the Japanese version. 
The study group of the Chinese history of science and technology studies led by Yabuuchi systematically organized and investigated various topics in the Chinese history of science. Their excellent research are reflected in publications such as the “Studies on History of Science and Technology in Ancient China: 《中国古代科学技 术史研究》" (1959), “Studies on History of Chinese Science and Technology in the Medieval China: 《中国中世科学技术史研究》” (1963) and “Studies on History of Science and Technology in the period of Sung and Yuan: 《宋元时代科学技术史研究》" (1967). Besides these milestones, Yabuuchi also co-authored with Yoshida Mitsukuni ( 吉田光邦) and published "A Study of History of Science and Technology in the period of Ming and Qing" (1970).

These publications indicate that the research carried out by the study group initially focused on a single subject on the studies of science of astronomy and calendar. Subsequently, the research focus shifted to general subjects. The scope of research began from the ancient times to Medieval, Song and Yuan dynasties, and right up to Ming and Qing dynasties. The group accumulated a large collection of general history of science and technology in China and laid down the foundation for future researchers. In essence, Yabuuchi was the pioneer for studies on the period history of science and technology as well as general history of China.

Yabuuchi also solely published “Science in Ancient China: 《中国古代的科学》" (1964); “An Explanation of the Islamic calendar in China: 《囸囸暦解》” (1964) and the "History of Science and Technology in China: 《中国科学技术史》" (1979). These publications and research findings were the fourth contribution of Yabuuchi to the study of the Chinese history of science and technology.

It is important to note that Professor Yabuuchi was the first to use spherical models such as deferent, equant and epicycle models as well as trigonometry theory to explain the Islamic calendar which was transmitted to China in the medieval age. This means that before Yabuuchi's discovery, Chinese scholars did not have a good understanding of the Islamic calendar. In the Room for the History of Science and Technology Studies, Yabuuchi carried out many projects and trained a number of famous researchers in the history of science and technological studies. Because of his influence through his research, public lectures and workshops, many Japanese scholars were interested to specialize in the Chinese history of science and technology. As a result, Yabuuchi taught students who later became world famous scholars. For example, his students included Yoshida Mitsukuni (吉田光邦: 1921-1991), Yamada Keiji (山田慶兒), Nakayama Shigeru (中山茂), Tanaka Awa (田中淡) and Hashimoto Takashi Miyatsuko (橋本敬造) who emerged as leading scholars and respected figures in the field of the Chinese history of science and technological studies. These students of Yabuuchi also trained a new generation of scholars. In so doing, Yabuuchi's knowledge was passed down from one generation to the next. This was his fifth contribution to the Chinese history of science. Yabuuchi also acted as an official academic mentor supervising foreign scholars and researchers from the United States, Austria and Australia, who specialized in the Chinese history of science and technology; these researchers included Nathan Sivin, a famous American professor on Chinese history of science and technology. Since Yabuuchi was a scholar who was able to pass on his knowledge and produce talented scholars and researchers globally, this act became his his sixth contribution.

In 1959, Professor Yabuuchi went to Tehran University as a visiting professor. Yabuuchi opened doors for young Japanese scholars to visit the Iran and subsequently 
many Japanese scholars visited Tehran. In the same year, he went to Barcelona and Madrid to attend the $9^{\text {th }}$ International Conference on the History of Science and Technology where he met Joseph Needham, a British scholar who was a famous academic of Chinese history of science and technology and was the author of "Science and Civilization in China." At the conference, meeting for the first time, Joseph Needham and Yabuuchi represented the western and eastern scholarship of Chinese history of science and technology. Yabuuchi was only well known in the East because he wrote in Japanese but Joseph Needham was better known internationally because he wrote in English. Hence, Joseph Needham's works are available worldwide and Yabuuchi's works are not. Nevertheless, I consider both of them to be great scholars.

In 1961, Yabuuchi was elected as a communication fellow by Academia Internationale, Histoire des Sciences in Paris. In 1965, Yabuuchi became a full fellow. From 1967 to 1969, Yabuuchi held the directorship of the Institute of Humanity (Jinbun: Human Science) Studies at Kyoto University. Yabuuchi led his study group until retirement in 1969. For his contributions and upon his retirement in 1969, Kyoto University honored him with the title of Professor Emeritus. The Room for History of Science and Technology Studies was handed over to Yanuuchi's student, Yamada Keiji (山田慶兒) who became the most famous Japanese scholar after Yabuuchi on Chinese history of science and technology, including Islamic science and calendar of China. For Yabuuchi, retirement marked the start of a new journey. From 1969 to 1979, Yabuuchi was appointed as a full-time professor working at Ryukoku University, Kyoto (京都 龙谷大学). Yabuuchi was awarded many honours by various organizations after his retirement. In 1970, Yabuuchi won the Asahi Bunka Medal (朝日文化奖) because of his great work related to "Chinese astronomy and calendars: 《中国的天文历法》" (1969). In the same year, he was awarded the Murasaki Hōshō medal (绶勋章) by the Japanese government. In 1972, American Association of History of Science awarded him the George Sarton Medal (萨顿奖章). In 1976, the Japanese government awarded him the Ni tō mizu takara Medal (二等瑞宝勋章). In 1983, he was elected as a committee member and fellow of the Japan Academy (日本学士院会员). Besides these contributions and recognitions, Professor Yabuuchi also served in many societies of academia; for example, he once held the post of juror (Hyōgi in: 評議員) at Japanese Association of Astronomy. He was elected as a committee member in many associations such as at the Science of Astronomy Association, History of Science and Philosophy of Japan Academy, International Association of Science of Astronomy and Association of East Asian Studies. These involvements reflected his contributions to Japanese as well international communities.

After his retirement at the age of sixty, Yabuuchi tirelessly published, simplifying his research and shared them with Japanese readers and scholars from History of Natural Science, China Academy of Science through letters and public lectures on the history of science and technology. He also appeared on local TV programs and regularly wrote in the public media such as newspapers and bulletins to share his knowledge. He summarized all his public lectures into a collection of works and published them. Some of his more recent published books are "Science and Civilization in China: 《中 国的科学与文明》" (1970); “Science of China and Japan: 《中国的科学与日本》" (1972); “The formation of Chinese Civilization: 《中国文明之形成》" (1974); “The Collection of Chinese Science of Astronomy and Mathematics: 《中国天文学、数学著作集》" (1980); and "From History of Science and Technology to View Chinese Civilization: 
《从科学史看中国文明》" (1982). In the 1980s, he also published some articles, for example, “Matteo Ricci ${ }^{1}$ and Ferdinand Verbiest ${ }^{2}$ : 《利瑪瑻和南懷仁》” (1982), and “Complementary to Biography of Song Yingxing: 《关于宋应星传的补遗》” (1984).

In his eighties, due to ill health, Yabuuchi's work slowed down. Yabuuchi visited China before the Sino-Japan war. From 1949 to 1969, while he was serving at Kyoto University, Yabuuchi did not have a chance to visit China as there were no diplomatic relations between China and Japan. Despite this limitation, he showed a friendly attitude towards the Chinese and their culture. He made every effort to promote Chinese history of science and technology to Japan and the world; he also tried to build a bond of friendship and mutual understanding between the two countries. Yabuuchi has many friends and fans in China, and I am one of them. His article "An Explanation of the Islamic Calendar" was well cited by many Chinese scholars in writings about how the Islamic calendar was introduced to China in the early Ming era. In fact, this article inspired me to study about him and write this particular paper. In 1990, Yabuuchi and Professor Yamada Keiji (山田慶兒) both were invited and honored with the title of Professor Emeritus by Institute of History of Natural Sciences, China Academy of Science, China. Yabuuchi came to China along with his wife and his dream to visit the country officially was finally fulfilled.

On June 2, 2000, Japan and China lost a great scholar of Chinese history of science and technology, and the world lost a doyen of history of Chinese science with the demise of Professor Yabuuchi Kiyoshi at the age of 94 in Kyoto. There are many socalled sinologists, who specialize in Chinese culture, history and philosophy around the world. However, few can match Joseph Needham and Yabuuchi Kiyoshi who specialized in the Chinese history of science and technology, and this is something worthy of respect and needs to be treasured. On a personal note, when I was reading a series of studies on an Islamic calendar manuscript transmitted to China in the early Ming Dynasty at the Department of Science and Technology Studies, Faculty of Science, University of Malaya, I frequently came across names of some experts such as E.S. Kennedy and David A. King, who are western scholars specializing in the Islamic science of astronomy and science of calendars (Ziji). When I tried to understand the Islamic calendar manuscript in the Chinese version, Qi Zheng Tui Bu (Chinese: 七政 推步) or Az-Zij al-Jami wal-Baligh (Arabic version) transmitted to China in the early Ming Dynasty, I frequently came across a Chinese name, Sou Nei Qing (薮内清). Sou was the only scholar who could explain how the Islamic calendar works in spherical models and trigonometry theory systematically. I was impressed and convinced with the explanation. This name was cited frequently in many publications written in the Chinese language by many Chinese scholars such as Yang and Yu (1995) and Chen (2008). I first got a copy of Yabuuchi's China's Astronomy and Calendars- 《中国の 天文曆法》 (平凡社, 1990, $2^{\text {nd }}$ ed.) and other materials written by him, but I did not manage to obtain a copy of "An Explanation of the Islamic calendar". When Professor Tomizawa Hisao visited the University of Malaya in 2013, I took the opportunity to ask him for help to get a copy of the Islamic Calendar authored by Yabuuchi. After Professor Tomizawa went back to Japan, he sent me a copy of "An Explanation of the Islamic calendar" authored by Yabuuchi Kiyoshi in 1964. Yabuuchi Kiyoshi explained the Islamic calendar manuscript, Qi Zheng Tui Bu with spherical models, theory of

1 Matteo Ricci, S.J. (1552-1610) was an Italian Jesuit priest, and one of the founding figures of the Jesuit China Mission, as it existed in the 17th-18th centuries.

2 Ferdinand Verbiest (1623-1688) was a Flemish Jesuit missionary in China during the Qing dynasty. He was born in Pittem near Tielt in Flanders, later became part of the modern state of Belgium. He is known as Nan Huairen in Chinese. 
trigonometry and algorithm, a method that Chinese scholars traditionally had little knowledge of. Chinese scholars such as Gu Guan-guang (谷观光) tried to explain the Islamic calendar in the Qing Dynasty, but failed until Yabuuchi wrote his introduction to the Islamic calendar in China. Yabuuchi's efforts in the research of Chinese history of science encouraged me to research on the Chinese history of science and technology, especially the Islamic science of astronomy and calendrical technology transmitted to China in the Ming era. I write this paper to remember the great contributions made by Yabuuchi Kiyoshi to the Chinese history of science and technology.

\section{Conclusion}

Yabuuchi was one of the pioneer scholars on the Chinese history of science of technology from the East. He contributed greatly through his academic publications, research and supervision. Yabuuchi's influence spread globally. From 1943 to 1990, Yabuuchi wrote 29 books and 55\% (16 books) of them were directly related to the Chinese history of science. His first book was the "Chinese Astronomy" (1943) and the last book that he wrote was "Astronomy and Calendrical Science in China" (revised and enlarged edition, 1990). From 1943 to 1980, Yabuuchi edited about 10 books and $70 \%$ (7 books) of them were related to the Chinese history of science. The first book that he edited was the "Culture in India" (1943) and the last edited book was the "Science and Mathematics in China" (1980). From 1932 to 1996, Yabuuchi translated about 19 publications, including books and articles, and 58\% (11) of them were directly related to the Chinese history of science. His last translation work was "Mozi" - a school of thought which was against Confucianism. From 1932 to 1999, Yabuuchi published about 190 articles in journals and newspapers, and 53\% (101) of them were directly related to the Chinese history of science. Yabuuchi also wrote eight publications related to the Islamic science of astronomy and calendrical technology in China. Yabuuchi's essay on "An Explanation of the Islamic calendar" was key to understanding the Islamic calendar manuscript transmitted to China in the early period of Ming Dynasty. The three scholars in the field of Chinese history of science, Yabuuchi Kiyoshi, Joseph Needham and Luther Carrington Goodrich enjoyed long life on this earth. Yabuuch lived to about 94 years (1906-2000), Joseph Needham lived to about 95 years (1900-1995) and Luther Carrington Goodrich lived to 92 years (1894-1986). Although we may not be as knowledgeable as they were, we should at least learn from them how to live a long life productively. In conclusion, Professor Yabuuchi was a knowledgeable scholar and productive scholar of Chinese history of science. His publications were op numerous that when stacked, the publications were rumoured to be could be as tall as his him. More importantly, Yabuuchi was also a humble man, and he is my role model as an academician.

\section{Selected References}

Benno van Dalen, "Islamic Astronomy in China during the Yuan and Ming Dynasties (translation and partial revision of a chapter from a book by Kiyosi Yabuuti)", Historia Scientiarium 7,1997, pp 11-43.

Benno van Dalen, Islamic Astronomical Tables in China: The Sources for the Huihui li, in History of Oriental Astronomy". Proceedings of the Joint Discussion-17 at the 23rd General Assembly of the International Astronomical Union, organised by the 
Commission 41 (History of Astronomy) held in Kyoto, August 25-26, 1997 (S.M. Razaullah Ansari, editor), Dordrecht (Kluwer) 2002, pp 19-31.

Catherine Jami, "In Memory of Prof. Kiyosi Yabuuti Presentation”, East Asian Science, Technology and Medicine (EASTM) 18, 2001, pp 10-12.

Collections of Journal of Oriental Studies (online) from vol.1 to vol.76, 《东方学报》总 目 (1-76)

Ho, Peng Yoke, "Kiyosi Yabuuti: A Personal Appreciation”, Needham Research Institute Newsletter, East Asian History of Science Trust, Newsletter No. 29, October, 2000.

Pan, Jixing, "In memory of Professor Sou Nei Qing, A Scholar in History of Science", China Historical Materials of Science and Technology, Vol. 22, No. 1, 2001, pp1-7.

Togo Toshihiro, "Bibliography of the Late Prof. Yabuuti Kiyosi", East Asian Science, Technology, and Medicine (EASTM), Volume 18, 2001, pp134-167

Yano Michio and H. Kawahara, "Japanese Contribution to the History of Chinese Science", Historia Scientiarum, Vol.6, No.2, 1996, pp 123-158.

Yano Michio, "Yabuuti Kiyosi as a Historian of Exact Sciences", East Asian Science, Technology and Medicine, No. 18, 2001, pp 13-19.

Yano Michio, "Kiyosi Yabuuti (1906-2000)", Archives Internatinales d'histoire des science, Vol. 51 200), p.155-157. 